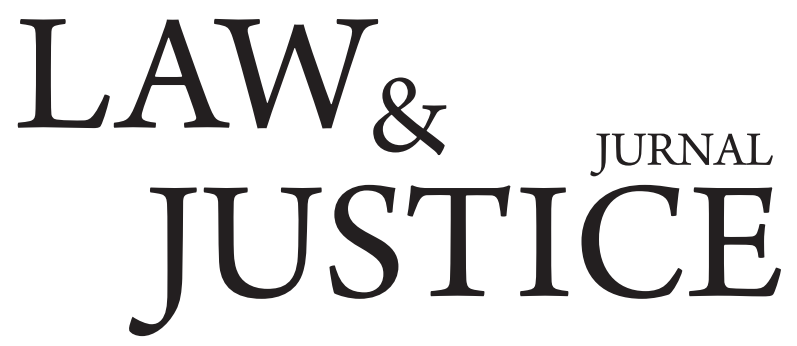

Volume 3, Nomor 2, Oktober 2018

\title{
PELAKSANAAN PERJANJIAN LEASING DAN PERMASALAHANNYA PADA PT SWADHARMA INDOTAMA FINANCE SEMARANG
}

\author{
Sukmawati \\ Program Studi Magister Ilmu Hukum Universitas Diponegoro \\ Jl. Imam Bardjo, S.H. No. 1-3 Semarang 50241 \\ Email: Shukma704@gmail.com
}

\begin{abstract}
Abstrak
PT. Swadharma Indotama Finance Semarang merupakan perusahaan leasing yang pelaksanaan perjanjiannya dalam bentuk perjanjian tertulis dan berupa akta otentik. Apabila lessee tidak memenuhi kewajibannya sesuai dengan perjanjian, lessor mempunyai alat bukti yang cukup kuat untuk mengenakan tindakan. Apabila lessee melakukan keterlambatan pembayaran angsuran maka lessor berhak memberi denda yang besarnya telah ditentukan sesuai dengan perjanjian yang telah disepakati. Apabila lessee sudah tidak mampu membayar angsuran, maka semua pembayaran (uang muka + angsuran leasing) yang telah dilakukan dianggap hangus, karena diperhitungkan sebagai biaya sewa atas barang lease yang pernah digunakan, selain itu lessor berhak menarik kembali atau menyita objek leasing.
\end{abstract}

Kata kunci: Finance, leasing, lessee, lessor, barang lease.

\section{Pendahuluan}

Perkembangan dalam suatu masyarakat terlihat pada perkembangan yang ada pada masyarakat tersebut baik di bidang ekonomi, sosial, budaya dan politik. Sejalan dengan meningkatnya kegiatan pembangunan nasional peran serta pihak swasta dalam pelaksanaan pembangunan akan semakin ditingkatkan pula. Keadaan tersebut baik langsung maupun tidak langsung akan menuntut lebih aktifnya kegiatan dibidang pembiayaan. Berbagai upaya dalam menghimpun dana masyarakat telah dilakukan dengan penetapan kebijaksanaan pemerintah. Pada hakikatnya perluasan usaha memang membutuhkan pembiayaan dana dan peralatan modal. Pembiayaan dana selain melalui sistem perbankkan dan lembaga keuangan non bank yang telah lama kita kenal, kita juga mengenal sistem pembiayaan alternatif lainnya, yakni sistem bisnis "leasing"'.

Sewa guna usaha (leasing) sebagai salah satu sistem pembiayaan mempunyai peranan dalam peningkatan pembangunan perekonomian nasional. Usaha leasing dapat membantu badanbadan dan pengusaha-pengusaha di Indonesia, terutama pengusaha industri kecil. Dalam mengatasi cara pembiayaan untuk memperoleh

1 Amin Widjaja Tunggal dan Arif Djohan Tunggal, Akutansi Leasing (Sewa Guna Usaha), (Jakarta:Rineka Cipta,2001), hal.5 
alat-alat perlengkapan maupun barang-barang modal yang mereka perlukan juga berarti meningkatkan pembangunan perekonomian nasional ${ }^{2}$.

Pembiayaan investasi melalui lease lebih memberikan kemudahan-kemudahan dibandingkan dengan pembiayaan melalui pinjaman dari bank. Hal ini terutama berlaku bagi usaha yang baru didirikan, yang mana belum mempunyai asset yang dapat dijadikan sebagai collateral (jaminan) bagi pinjaman yang akan diperoleh dari bank. Dalam lease pengusaha tidak perlu menyediakan jaminan karena asset yang diperoleh melalui lease sekaligus merupakan jaminan bagi perusahaan leasing ${ }^{3}$.

Meskipun lembaga leasing tidak dikenal dalam KUH Perdata, tetapi dikenal dalam prakteknya. Dalam bahasa Indonesia istilah leasing diterjemahkan dengan kata "sewa guna usaha". Di Indonesia kegiatan leasing ini baru diperkenalkan pada tahun 1974. Pasal 1 angka 5 Peraturan Presiden Republik Indonesia Nomor 9 Tahun 2009 Tentang Lembaga Pembiayaan, yang dimaksud sewa guna usaha (leasing) adalah kegiatan pembiayaan dalam bentuk penyediaan barang modal baik secara sewa guna usaha dengan hak opsi (Finance Lease) maupun sewa guna usaha tanpa hak opsi (Operating Lease) untuk digunakan oleh penyewa guna usaha (Lessee) selama jangka waktu tertentu berdasarkan pembayaran secara angsuran.

PT. Swadharma Indotama Finance (PT. SIF) Semarang merupakan perusahaan sewa guna usaha (leasing company) yang mempunyai 3 (tiga) jenis layanan pembiayaan, yaitu sewa guna usaha, pembiayaan konsumen dan anjak piutang. PT. SIF Semarang memiliki misi dan visi membantu pembangunan nasional melalui jalur pembiayaan sarana transportasi umum, didukung oleh jaringan usaha yang luas dari Indomobil dan fasilitas perbankan yang dimiliki oleh Bank Negara Indonesia yang telah memiliki jaringan ke pelosok tanah air, maka lingkup pembiayaan PT. Swadharma Indotama Finance (PT. SIF) juga tersebar ke seantero nusantara dan telah memiliki 11 (sebelas) cabang, yakni Jakarta Barat, Jakarta Utara, Semarang, Purwokerto, Medan,

2 Achmad Anwari, Leasing di Indonesia, (Jakarta:Ghalia Indonesia,1987), hal.14

3 Amin Widjaja Tunggal dan Arif Djohan Tunggal, Aspek Yuridis Dalam Leasing, (Jakarta:Rineka Cipta,2001), hal.2
Bandar, Lampung, Yogyakarta, Bogor, Bandung, Surabaya, Denpasar.

Pola pembiayaan yang cepat diterapkan kepada konsumen akhir melalui dealer kendaraan yang telah ada kerja sama dengan PT. Swadharma Indotama Finance Semarang. Namun dengan penuh pertimbangan dan kehatihatian serta sistem pembayaran angsuran yang telah dirancang sedemikian rupa, sehingga mudah dan aman merupakan salah satu keuanggulan PT . Swadharma Indotama Finance (PT. SIF) Semarang. Dalam prakteknya pelaksanaan perjanjian leasing pada PT. Swadharma Indotama Finance Semarang sering terjadi permasalahan. Salah satunya dikarenakan lessee tidak memenuhi kewajibannya sesuai dengan perjanjian.

\section{Rumusan Masalah}

1. Apa saja permasalahan yang timbul dalam pelaksanaan perjanjian leasing pada PT. Swadharma Indotama Finance Semarang dan cara penyelesaiannya?

2. Bagaimana hak dan kewajiban para pihak dalam pelaksanaan perjanjian leasing pada PT Swadharma Indotama Finance Semarang?

\section{Metode Penelitian}

Metode penelitian yang digunakan adalah metode pendekatan yuridis sosiologis, yaitu penelitian yang mencari, menafsirkan, dan membuat kesimpulan berdasarkan kenyataan atau fenomena empirik yang terjadi di masyarakat ${ }^{4}$.

\section{Hasil Penelitian dan Pembahasan}

1. Permasalahan yang timbul dalam pelaksanaan perjanjian leasing pada PT. Swadharma Indotama Finance Semarang dan cara penyelesaiannya.

Permasalahan yang dihadapi PT. Swadharma Indotama Finance Semarang dalam pelaksanaan perjanjian leasing adalah sebagai berikut :

a. Lessee terlambat dalam melakukan pembayaran angsuran baik sebagian maupun seluruhnya dari waktu yang telah ditentukan.

4 Ronny Hani Tijo Soemitro, Metodologi Penelitian Hukum, (Jakarta:Ghalia Indonesia,1982), hal.30 
b. Lessee tidak membayar denda atas keterlambatannya membayar uang sewa.

c. Lessee tidak dapat melunasi lagi sebagian atau seluruh hutangnya atau tidak memenuhi kewajibannya menurut ketentuan dalam perjanjian atau memang dengan sengaja Lessee tidak membayar sewa yang telah jatuh tempo pembayarannya.

d. Lessee melakukan tindakantindakan yang dilarang dilakukannya sesuai perjanjian yang telah disepakati bersama, umpamanya meminjamkan, menggadaikan, atau memindahtangankan barang lease kepada orang lain dan sebagainya.

e. Terjadinya suatu kerusakan atau kehilangan atas barang lease.

f. Adanya keterbatasan modal usaha lessor seiring dengan semakin meningkatnya jumlah pengusaha atau masyarakat pada umumnya yang mengajukan permohonan pembiayaan pembelian barang lease.

Penyelesaian terhadap permasalahan tersebut di atas adalah sebagai berikut :

a. Apabila Lessee terlambat dalam membayar angsuran, maka pertamatama pihak lessor akan memberikan teguran secara lisan dan tertulis supaya membayar angsuran, jika teguran tersebut tidak digubris maka lessee akan dikenakan denda dan harus membayar denda yang besarnya telah ditentukan oleh lessor.

b. apabila lessee tidak membayar denda atas keterlambatan pembayarannya, maka pihak lessor akan memberikan teguran baik secara lisan maupun tertulis kepada lessee, serta dengan menarik suatu deposito guna menjamin ketaatan lessee terhadap perjanjian leasing yang akan dikembalikan lagi kepada lessee pada masa berakhirnya perjanjian leasing dengan dikurangi jumlah-jumlah yang harus dibayar oleh lessee.

c. Dalam hal lessee tidak dapat melunasi hutangnya baik sebagain atau seluruhnya, setelah diberi teguran baik lisan maupun tulisan, maka lessor berhak mengambil/menyita dimanapun dan ditempat siapapun barang lease tersebut berada. Mengingat lessor memiliki hak subtitusi yaitu hak untuk mengambil/menyita dimanapun dan ditempat siapapun barang lease tersebut berada dengan menunjukkan surat keterangan penarikan barang lease dari pihak lessor. Lessor juga dapat menjual dengan perantara siapapun barang lease tersebut setelah ditarik oleh lessor, maka lessor berhak penuh melaksanakan penjualan atas barang lease tersebut. Hasil penjualan akan dipakai untuk melunasi hutang lessee, termasuk membayar semua ongkos dan pajak lainnya. Apabila hasil penjualan ternyata masih ada sisanya, lessor akan menyerahkan sisa itu kepada lessee. Sebaliknya apabila uang hasil penjualan itu tidak cukup untuk melunasi hutang lessee kepada lessor, maka lessee tetap berkewajiban membayar sisa hutang tersebut kepada lessor.

d. Apabila lessee telah terbukti meminjamkan, menggadaikan, menjual, atau memindahtangankan barang lease tersebut kepada orang lain, maka lessor akan menarik kembali/menyita barang lease dari lessee.

e. Rusak atau hilangnya barang lease menjadi tanggung jawab lessee. Lessee akan bekerja sama dengan perusahaan asuransi, sehingga yang mengganti atas rusak atau hilangnya barang lease adalah perusahaan asuransi.

f. Untuk mengatasi keterbatasan modal usaha leasing, maka lessor berusaha mengadakan kerjasama dengan salah satu bank atau instansi lain.

Bahwa selama lessee belum membayar lunas seluruh harga barang lease, maka barang lease yang tercantum dalam perjanjian yang telah diserahkan oleh lessor kepada lessee tetap masih berstatus barang pinjaman. Lessee selaku peminjam harus bertanggung jawab penuh terhadap barang lease dan tidak berwenang untuk memindah tangankan, menggadaikan, menjual, memindah alamatkan, 
maupun perbuatan lainnya yang bertujuan untuk memindah tangankan barang lease tersebut.

\section{Hak Dan Kewajiban Para Pihak Dalam}

Pelaksanaan Perjanjian Leasing Pada PT Swadharma Indotama Finance Semarang.

Dalam pelaksanaan perjanjian leasing pada PT Swadharma Indotama Finance Semarang prosedur pengajuan barang lease melalui 4 (empat) tahap yaitu tahap negosiasi, tahap penandatanganan dokumen, tahap penyerahan modal dan tahap sewa atau angsuran leasing. Adapun pelaksanaan perjanjian tersebut menimbulkan hak dan kewajiban bagi para pihak yaitu pihak lessor, lessee dan supplier, sebagai berikut:

\section{a. Pihak lessor}

1. Hak

a) Sebagai pemberi jasa leasing, lessor berhak menerima imbalan dari lessee dalam bentuk pembayaran secara berkala;

b) Mengenakan denda lessee apabila terjadi keterlambatan dalam pembayaran angsuran;

c) Jika lessee tidak melunasi sebagian atau seluruh hutangya atau tidak memenuhi kewajibannya menurut ketentuan dalam perjanjian, maka lessor berhak mengambil barang lease tersebut, dan menjual kepada siapapun barang lease yang telah diambil tersebut. Hasil penjualan akan dipakai untuk melunasi hutang lessee;

d) Sewaktu-waktu dapat merubah suku bunga, provisi, dan denda tersebut sesuai dengan keadaan tanpa pemberitahuan terlebih dahulu kepada lessee;

e) Menerima uang ganti kerugian dari perusahaan asuransi apabila terjadi kerusakan atau kehilangan barang yang disewakan.
2. Kewajiban

a) Memberikan jasa pengadaan barang modal yang dibutuhkan lessee selama masa perjanjian leasing;

b) Membayar kekurangan harga barang lease dari lessee kepada supplier;

c) Member BPKB kepada lessee jika angsuran pembayaran telah lunas.

b. Pihak lessee

1. Hak

a) Memperoleh barang lease yang dibutuhkan dan bebas menggunakan barang tersebut;

b) Memperoleh potongan 1 (satu) persen dari jumlah angsuran per bulan apabila fasilitas pembayaran yang telah diterimanya dilunasi lebih awal dari waktu yang telah dijanjikan;

c) Memperoleh klaim asuransi;

d) Mendapat tenggang waktu pembayaran selama 2 (dua) hari;

e) Mendapat BPKB dari lessor jika angsuran telah lunas;

f) Melunasi pembayaran angsuran sebelum waktunya.

2. Kewajiban

a) Wajib datang sendiri ke kantor PT. Swadharma Indotama Finance Semarang atau diwakili untuk membayar angsuran tepat waktu;

b) Membayar denda untuk setiap keterlambatan pembayaran angsuran;

c) Memelihara dan merawat barang lease dengan sebaikbaikknya;

d) Menanggung ongkosongkos, pajak-pajak, biayabiaya pemeliharaan dan perawatan yang berhubungan dengan barang lease;

e) Tidak akan menyewakan, meminjamkan, menjaminkan 
atau memindahtangankan barang lease pada pihak lain;

f) Bertanggung jawab penuh atas barang lease apabila barang tersebut hancur, rusak, tabrakan, hilang, lease tetap berkewajiban membayar angsuran setiap bulannya;

g) Wajib mengasuransikan barang lease terhadap bahaya kebakaran dan bahaya lainnya dengan jumlah yang ditetapkan lessor dan melalui perusahaan yang ditunjuk lessee atau lessor dengan ini menunjuk lessor sebagai penerima asuransi.

c. Pihak Supplier

1. Hak

a) Menerima pembayaran dan kekurangan harga barang lease dari lessor.

2. Kewajiban

a) Menyerahkan barang lease kepada lessee secara fiducia.

b) Menyerahkan dokumendokumen yang berhubungan dengan barang lease tersebut.

Semua hak dan kewajiban yang timbul berdasarkan perjanjian ini dapat dialihkan oleh lessor kepada siapapun tanpa memerlukan persetujuan dari lessee. Kuasa dalam perjanjian ini tidak dapat ditarik kembali, serta tidak dapat berakhir dengan alasan apapun selama lessee masih mempunyai hutang kepada lessor atau belum memenuhi semua kewajibannya terhadap lessor.

\section{Kesimpulan}

PT. Swadharma Indotama Finance Semarang dalam menyelenggarakan jasa pembiayaan pembelian barang-barang modal dituangkan dalam bentuk perjanjian tertulis dan berupa akta otentik. Sehingga apabila lessee tidak memenuhi kewajibannya sesuai dengan perjanjian maka lessor mempunyai alat bukti yang cukup kuat untuk mengenakan tindakan terhadap lessee. Apabila lessee melakukan keterlambatan pembayaran angsuran maka lessor berhak memberi denda yang besarnya telah ditentukan sesuai dengan perjanjian yang telah disepakati. Apabila lessee sudah tidak mampu lagi melunasi pembayaran angsuran, maka semua pembayaran (uang muka + angsuran leasing) yang telah dilakukan lessee dianggap hangus, karena diperhitungkan sebagai biaya sewa atas barang lease yang pernah digunakan, selain itu lessor berhak menarik kembali atau menyita objek leasing tersebut.

\section{Daftar Pustaka}

Ronny Hani Tijo Soemitro .(1982). Metodologi Penelitian Hukum, Jakarta: Ghalia Indonesia

Anwari, Achmad.(1987). Leasing di Indonesia Jakarta: Ghalia Indonesia

Arif Djohan Tunggal, Amin Widjaja Tunggal, .(2001). Akutansi Leasing (Sewa Guna Usaha), Jakarta: Rineka Cipta

Arif Djohan Tunggal, Amin Widjaja Tunggal, .(2001). Aspek Yuridis Dalam Leasing, Jakarta: Rineka Cipta

Peraturan Presiden Republik Indonesia Nomor 9 Tahun 2009 Tentang Lembaga Pembiayaan. 